\title{
Rola uniwersytetów w promocji polskich miast i regionów nowe wyzwania strategiczne
}

\section{Wprowadzenie}

W kontekście najnowszej praktyki marketingu — zarówno marketing terytorialny, jak i marketing akademicki są nowymi obszarami zastosowań podejścia marketingowego. Ich dynamiczny rozwój w Europie i na świecie nastąpił w ciagu ostatnich 15-20 lat (1990-2010).

Z kolei w Polsce możemy mówić o intensywnym rozwoju obu tych dziedzin praktycznie dopiero od końca lat dziewięćdziesiątych lub od początków XX w. W naszym kraju są to więc zupełnie nowe pola dla działań marketingowych, które wymagają od menedżerów oraz od pracowników administracji terytorialnej, stworzenia spójnego podejścia, łączącego w harmonijny sposób cele strategiczne podmiotów akademickich oraz samorządu terytorialnego na szczeblu miast i regionów.

W warunkach polskich obie dziedziny rozwijały się do tej pory najczęściej równolegle bez odpowiedniej koordynacji oraz spójnej wzajemnej komunikacji marketingowej. Paradoksalnie bowiem, choć powinny się one wzajemnie przenikać i dopełniać, to w zbyt małym stopniu wykorzystywano dotychczas instrumenty niezbędne dla zapewnienia wzajemnej synergii oraz koordynacji celów strategicznych.

Wynikało to zarówno z braku jasnych i klarownych metod wypracowania strategii na poziomie akademickim (niski stopień orientacji rynkowej uniwersytetów państwowych), jak również z niedostatków orientacji marketingowej na poziomie samorządów miast i regionów.

Wydaje się, iż strategie rozwoju polskich miast i regionów były dotychczas w zbyt małym stopniu skorelowane z potencjałem strategicznym uczelni wyższych, działających 
na ich terenie. Wynikało to niekiedy ze zbyt słabego udziału uczelni wyższych w procesie kreowania tych strategii. Opracowywanie strategii marketingu terytorialnego powierzano często podmiotom zewnętrznym, spoza regionu, zamiast wypracowywania ich wspólnie w ścisłej współpracy z uczelniami akademickimi działającymi na danym terenie.

W kontekście coraz szybciej zmieniającego się rynku i to zarówno w odniesieniu do uczelni akademickich, jak i miast i regionów — konkurujących między sobą o inwestycje zagraniczne oraz o inwestorów krajowych, w sposób naturalny pojawiła się konieczność wypracowania nowych bardziej spójnych i skoordynowanych mechanizmów wzajemnej współpracy.

Ta nowa sytuacja wymusza na obu podmiotach poszukiwania nowego komplementarnego pozycjonowania oraz kreowania korzystnego dla obu stron mechanizmu budowania relacji partnerskich — służących realizacji wspólnie uzgodnionych celów strategicznych.

Nowa bardziej konkurencyjna sytuacja rynkowa stwarza także konieczność zadania pytania o to, w jakim stopniu efektywny marketing akademicki może być atutem dla marketingu terytorialnego w procesie kreowania atrakcyjnej oraz trwałej konkurencyjnej przewagi miasta i regionu oraz budowania jego wizerunku dla ważnych i rozwojowych w przyszłości grup adresatów w kraju i za granica.

\section{Marketing akademicki w poszukiwaniu swojej tożsamości}

Marketing akademicki jest młodą dziedziną — poszukującą niewątpliwie swej rynkowej tożsamości. Tradycyjna oraz historyczna tożsamość uniwersytetów w dużym stopniu, jeśli nie całkowicie, abstrahowała od czynników rynkowych. Wynikało to przed wszystkim z faktu, iż w przeszłości uniwersytet nie podlegał bezpośrednio presji rynku, co pozwalało jego władzom nie dostrzegać rynku lub wręcz go programowo ignorować.

Nowe podejście do marketingu akademickiego każe przede wszystkim zadać pytanie o to, do jakich segmentów odbiorców lub inaczej — do których adresatów zamierzamy kierować naszą ofertę.

Różne definiowanie grup adresatów ma bowiem swe przełożenie na potencjalnych „klientów” oferty uniwersyteckiej. Ma to kapitalne znaczenie dla marketingu terytorialnego, gdyż to właśnie marketing akademicki decydować będzie w przyszłości o tym, ilu adresatów oferty akademickiej oraz jak długo będzie przebywać w danym ośrodku miejskim. Będzie to miało dla miast oraz regionów konsekwencje zarówno krótko- i średniookresowe, jak też długookresowe.

To bowiem uniwersytety oraz szkoły wyższe są tymi podmiotami, które generuja na danym rynku lokalnym najsilniejszy napływ przybyszów z zewnątrz, silnie skoncentrowany w czasie oraz cechujący się własnym cyklem życia (cykl 5-letni, 4-letni, 
3-letni, 2-letni, roczny lub krótszy — wynikający z różnych form kształcenia oraz doskonalenia wiedzy).

Ponadto, cykl ten może zostać przedłużony w zależności od atrakcyjności jakości życia w danym mieście lub regionie, co może zaowocować stałym transferem ludności do tego miasta oraz regionu.

Można założyć, iż w takim ujęciu marketing akademicki powinien być jednym z kluczowych wektorów definiowania strategii marketingu terytorialnego. Tożsamość marketingu akademickiego jest więc ściśle powiązana z tożsamością marketingu terytorialnego.

W takim podejściu marketing akademicki staje się kluczowym elementem atrakcyjnego pozycjonowania miasta oraz regionu.

\subsection{Różne podejścia do segmentacji rynku}

W segmentacji rynku usług akademickich podstawowym czynnikiem jest zakres geograficznego oddziaływania rynku. Możemy tutaj mówić o oddziaływaniu typowo lokalnym — o wąskim zasięgu — oraz o oddziaływaniu szerokim i stale poszerzającym się. Osoby odpowiedzialne za marketing akademicki powinny więc przede wszystkim posiadać wiedzę o zakresie geograficznym oddziaływania swego uniwersytetu. Wiedza ta powinna być z kolei podstawą budowania strategii marketingowych uczelni wyższej. W relacji z miastem i regionem wiedza ta powinna stanowić podstawę do wypracowywania wspólnych strategii, zarówno w kontekście komunikacji marketingowej oraz zarządzania marką miasta i regionu, jak również całościowej strategii rozwoju obu jednostek terytorialnych (miasta i regionu). Strategie tych podmiotów powinny być przede wszystkim spójne i oparte na wspólnie uzgodnionych celach. Ma to również kluczowe znaczenie dla strategii pozycjonowania miasta i regionu.

\subsection{Grupy docelowe w ujęciu lokalnym}

Segmentacja rynku w tym podejściu oznacza pozycjonowanie oferty uniwersyteckiej głównie pod kątem lokalnych adresatów, czyli mieszkańców danego miasta oraz regionu. Mamy tutaj do czynienia z typowym marketingiem wewnętrznym i dążeniem do największej penetracji rynku lokalnego. Na rynku tym konkurencja istnieje przede wszystkim między różnymi szkołami wyższymi, które zabiegają o tych samych adresatów.

Budowanie strategii opartej wyłącznie lub w przeważającej części na popycie pochodzącym z rynku lokalnego zawiera w sobie szereg ograniczeń i zagrożeń na przyszłość. Brak szerszego spojrzenia na rynek grozi bowiem jego zawężaniem i może mieć nieodwracalne skutki w zakresie spadku popytu. Takie podejście jest zasadne jedynie jako komplementarne do innych ujęć segmentacji (regionalnego, krajowego oraz międzynarodowego). Globalizacja oraz internacjonalizacja rynku edukacyjnego każe jednak spojrzeć na ten rynek w jego znacznie szerszej perspektywie (por. dalej).

W kontekście rynku lokalnego skutecznym czynnikiem mogącym stymulować popyt sa strategie dywersyfikacji gamy usług edukacyjnych. W przypadku uniwersy- 
tetów oznacza to dostrzeganie nowych grup adresatów, którzy wcześniej nie korzystali w ogóle z oferty usługowej lub korzystali z niej w bardzo niewielkim zakresie. W obszarze usług edukacyjnych są to głównie adresaci edukacji ustawicznej. W grupie tej znajdują się zarówno osoby starsze (Uniwersytety Trzeciego Wieku), jak i osoby dojrzałe uzupełniające swoją wiedzę (studia podyplomowe) oraz różne formy szkoleń specjalistycznych krótko- oraz średnio- i długoterminowe adresowane do różnych kategorii odbiorców (środowiska biznesu, administracja publiczna oraz samorządowa, pracownicy wybranych sektorów gospodarki oraz określone grupy i środowiska zawodowe etc.). Każda z tych grup oczekuje na stworzenie dla niej unikatowej oferty.

Wydaje się, iż w warunkach polskich, penetracja rynku lokalnego będzie w przyszłości bardziej dotyczyć dywersyfikacji oferty usług edukacyjnych (dywersyfikacja gamy produktowej) aniżeli dążenia przez uniwersytet do zwiększania udziału w tradycyjnych, segmentach rynku lokalnego. Majac bowiem do czynienia z nieodwracalnym zmniejszaniem się lokalnego popytu na klasyczne usługi edukacyjne, związane z kształceniem absolwentów szkół średnich (negatywny efekt nieodwracalnych zmian demograficznych), należy spodziewać się działań marketingowych nastawionych na szersze dotarcie do innych potencjalnych segmentów rynku lokalnego.

Kluczowym wyzwaniem marketingowym będzie więc poszukiwanie nowych segmentów rynku oraz kreowanie takiej oferty edukacyjno-doradczej, która byłaby dla tych segmentów atrakcyjna rynkowo. W ramach dywersyfikacji gamy usług duże możliwości znajdują się także w odniesieniu do szeroko rozumianego doradztwa oraz ekspertyz, świadczonych dla szerokiej gamy podmiotów zewnętrznych oraz osób.

W przypadku polskich uniwersytetów pojawia się również trend do tworzenia oferty edukacyjnej dla nowych — młodszych kategorii odbiorców. Proces ten przebiega m.in. przez tworzenie „Uniwersytetów Dziecięcych” oraz szkół średnich pod patronatem uniwersyteckim, w ramach struktur akademickich.

Mamy tutaj do czynienia z interesującym zjawiskiem polegającym na rozbudowywaniu gamy usług edukacyjnych dla odbiorcy lokalnego na różnych etapach jego cyklu życia (faza edukacji szkolnej, licealnej, akademickiej, podyplomowej oraz ustawiczne). Można w tym kontekście mówić o wartości życiowej klienta na lokalnym rynku akademickim. Jest to wyraźna próba związania lokalnego klienta z oferta uniwersytetu, w ciagu całego jego życia lub na pewnych jego etapach. Mamy tutaj także do czynienia z budowaniem systemu lojalności lokalnego adresata wobec „swojego uniwersytetu" i kreowaniem systemu długookresowych relacji z grupa lokalnych adresatów. Jest to klasyczna strategia dywersyfikacji oferty usługowej uniwersytetu w stosunku do tych samych lokalnych, a zarazem lojalnych adresatów. Strategię tę można określić jako ciagłe poszerzanie oraz różnicowanie oferowanej gamy usług, tak aby być atrakcyjnym partnerem dla lokalnych adresatów.

Mając lojalnych odbiorców na rynku lokalnym należy niewątpliwie poszerzać swą ofertę o nowe usługi atrakcyjne dla tej grupy. W odniesieniu do lokalnych segmentów rynku powinniśmy mieć do czynienia z komunikacją opartą na spójnym marketingu wewnętrznym akcentującym atrakcyjność oferty miasta, regionu oraz uniwersytetu 
zlokalizowanego na danym terenie. Wydaje się, iż komunikacja wewnętrzna może być tutaj ważnym wektorem budowania spójnego, a zarazem pozytywnego wizerunku uniwersytetu oraz miasta i regionu (efekt wyraźnej synergii na rynku wewnętrznym).

\subsection{Grupy docelowe w ujęciu regionalnym}

W odróżnieniu od orientacji typowo lokalnej, nastawionej bardziej na miasto jako podmiot oraz miejsce, orientacja regionalna uniwersytetu jest najbardziej oczywistą próbą poszerzenia rynku. Odwołuje się bowiem do adresatów żyjących w regionie, czyli w najbliższym sąsiedztwie miasta oraz uniwersytetu. Podejście to traktuje uniwersytet jako wyznacznik rozwoju oraz symbol metropolii miejskiej będącej potencjalnym stymulatorem rozwoju regionu.

Region obok miasta jest bowiem naturalnym adresatem oferty edukacyjnej uniwersytetu. Nowe ciążenia biznesowe (delokalizacja inwestycji, napływ inwestorów zagranicznych etc.) zwiększają zapotrzebowanie regionu na coraz bardziej atrakcyjną ofertę uczelni wyższych. Ta nowa oferta warunkuje wszelkie procesy rozwojowe i w sposób oczywisty powinna służyć rozwojowi regionu.

Z punktu widzenia strategii marketingowej uniwersytetów kluczową informacja jest wiedza o popycie na usługi akademickie w całym regionie i w jego wybranych częściach. Jest to informacja na temat naturalnych ciążeń na rynku edukacyjnym oraz na temat obecnego i potencjalnego popytu.

Adresaci oferty akademickiej w regionie są bowiem także w orbicie oddziaływania zarówno uniwersytetów zlokalizowanych w sąsiednich, a więc najbliższych regionach, jak również w regionach bardziej oddalonych, gdzie znajdują się również uniwersytety zabiegające o studenta.

Wydaje się, iż w polskich warunkach bardzo niewiele uczelni wyższych dysponuje zdezagregowaną wiedzą na temat ciążeń na rynku akademickich oraz na temat przepływów potencjalnych klientów.

Brak jest także badań na temat percepcji stolicy regionu, jako atrakcyjnego miejsca do studiowania, na tle stolic sąsiednich regionów. Zdobycie tego rodzaju informacji wymaga prowadzenia stałych badań marketingowych na temat potrzeb i zamierzeń edukacyjnych mieszkańców regionu oraz percepcji uczelni wyższych i stolicy regionu jako miejsca do studiowania oraz do życia.

Obok wiedzy o zachowaniach potencjalnych klientów w regionie istnieje pilna konieczność prowadzenia zintegrowanych działań marketingowych prze władze uniwersytetu oraz regionu. O wyborze miejsca do studiowania decydują bowiem zarówno elementy związane z wizerunkiem i marką uniwersytetu, jak i wizerunkiem miasta oraz regionu. Warto bardzo mocno podkreślić zarówno jakość życia w mieście, jak i wysoki poziom oraz atrakcyjność uniwersytetu jako miejsca do studiowania. Można więc zadać sobie pytanie, na ile te czynniki są wzajemnie spójne, a na ile istnieje między nimi dysonans poznaczy — osłabiający potencjalnych adresatów oferty akademickiej dla dokonania jej wyboru. 
Kluczowym problemem strategicznym jest tutaj doprowadzenie do jednolitego i atrakcyjnego wizerunku uniwersytetu oraz miasta — jako stolicy regionu, w którym znajduje się uniwersytet. W kontekście strategii konkurowania o studenta z regionu ważnym czynnikiem wizerunkowym jest budowanie atrakcyjnej wizji miejsca i jakości życia w tym miejscu, jako czynnika stymulującego wybory dokonywane przez potencjalnych klientów.

\subsection{Grupy docelowe w ujęciu krajowym}

Umiejętność przyciagania studentów spoza regionu jest prawdziwym testem dla jakości uniwersytetu, miasta oraz regionu. Wysoki współczynnik studentów spoza regionu ukazuje rzeczywisty poziom atrakcyjności danego uniwersytetu oraz miasta. Świadczy on również o dobrym wizerunku danej metropolii oraz o jej ponadregionalnej sile przyciąania. Dopełnieniem tego współczynnika powinna być analiza liczby osób spoza regionu, które zamierzają w nim pozostać po zakończeniu studiów, gdyż wiążą z nim swoją przyszłość i swoje dalsze plany. Wskaźnik ten najlepiej obrazuje atrakcyjność danego miasta jako miejsca o wysokiej jakości życia.

W ujęciu idealnym postrzeganie atrakcyjności miasta oraz atrakcyjności uniwersytetu — jako miejsc do studiowania — jest bardzo wysokie, co skutkuje dopełnianiem się oraz wzmacnianiem obu tych pozytywnych wizerunków. Zdecydowanym źródłem przewagi konkurencyjnej są unikatowe kierunki do studiowania dostępne jedynie na danej uczelni o trwałej i trudnej do skopiowania przewadze konkurencyjnej. Z uwagi na mobilność kadry profesorskiej oraz możliwość tworzenia nowych uczelni czynnik ten, jeśli nie jest konsekwentnie doskonalony, może jednak stopniowo tracić na znaczeniu.

Dodatkowym czynnikiem niwelującym przewage konkurencyjną tradycyjnych ośrodków akademickich może być szersze wykorzystywanie nowych technologii przez nowe szkoły wyższe, budujące w sposób bardzo ekspansywny swoją pozycję rynkową.

W przypadku bardzo niskiego wskaźnika udziału studentów spoza regionu w ogólnej zbiorowości studentów danej uczelni, należy wnioskować, iż jej oferta edukacyjna jest mało unikatowa i tym samym jej zasięg oddziaływania jest wąski. Niski poziom tego wskaźnika może świadczyć także o słabym poziomie postrzegania danego miasta jako atrakcyjnego miejsca do studiowania. Paradoksalnie w tych warunkach nawet dość dobre postrzeganie uniwersytetu przy niskiej ocenie atrakcyjności miasta jako miejsca do studiowania może bardzo negatywnie oddziaływać na ten potencjalny wybór.

\subsection{Grupy docelowe w ujęciu międzynarodowym}

Budowanie silnej pozycji uniwersytetu, miasta, regionu na rynku międzynarodowym może być oparte na dwóch strategiach.

Pierwsza z nich polega na długookresowym i konsekwentnym budowaniu pozycji marketingowej uniwersytetu oraz miasta i regionu. Strategia ta odwołuje się do pewnych tradycji oraz pozycji rynkowej miasta, regionu oraz uniwersytetu wypracowywanych latami. Jest ona skuteczna wyłącznie w odniesieniu do nielicznych uni- 
wersytetów o trwałej i ugruntowanej pozycji międzynarodowej. Dotyczy to zwykle najstarszych uniwersytetów, zlokalizowanych w renomowanych ośrodkach akademickich. W Polsce — z wyjątkiem Uniwersytetu Jagiellońskiego — strategia ta nie wydaje się mieć szerszego zastosowania. Wynika to z niskiej rozpoznawalności uniwersytetów oraz miast, w których są one zlokalizowane na arenie międzynarodowej.

Druga strategia opiera się natomiast na bardzo ekspansywnej polityce marketingowej, budowanej nowoczesnymi metodami komunikacji marketingowej wspólnie z miastem oraz regionem. Strategia ta zakłada daleko idącą synergię oraz podejście partnerskie — miasta, regionu oraz uniwersytetu. Podejście to polega na wspólnym definiowaniu celów w kontekście rozwoju regionu oraz dynamicznej strategii internacjonalizacji uniwersytetu.

Budowaniu partnerstwa miast i regionów towarzyszy świadome działanie polegające na budowaniu partnerstwa uniwersytetów tych miast i regionów. Dobór miast oraz regionów partnerskich nie jest więc tutaj przypadkowy, lecz wynika z pewnej spójnej strategii, polegającej na preferowaniu określonych kierunków rozwoju partnerstwa, jako kluczowych dla wszystkich zainteresowanych partnerów. W takim ujęciu działania te wzajemnie się dopełniają i odpowiadają wspólnym celom strategicznym.

Taka strategia polega na inicjowaniu wspólnych działań strategicznych w odniesieniu do pewnych regionów partnerskich oraz uczelni działających w tych regionach oraz w ich stolicach. Mamy tutaj więc do czynienia z wykorzystywaniem tej samej sieci powiązań dla kreowania nowych relacji w kontekście międzynarodowym. Strategia ta mieści się w formule marketingu aktywnego, gdzie cele rozwojowe regionu - w tym zwłaszcza cele inwestycyjne - splatają się z celami strategicznymi uczelni wyższych (nowe programy i centra innowacyjności oraz doskonałości).

Wydaje się, iż sfera pozycjonowania uniwersytetu oraz miasta i regionu na rynku międzynarodowym jest jednym z tych obszarów na którym w sposób naturalny moga i powinny spotykać się cele tych podmiotów w kontekście strategii internacjonalizacji. Podejście to wymaga stworzenia bardzo stabilnych zasad współpracy partnerów oraz koordynacji swych celów strategicznych. Strategie te powinny mieć charakter w pełni apolityczny i cechować się ciagłością, niezależnie od wyników lokalnych i regionalnych wyborów samorządowych. Czynnik ten ma kluczowe znaczenie w warunkach polskich, gdzie ciagle brak skutecznych mechanizmów dla realizacji wspólnych strategii marketingowych w tym zakresie.

\section{Marketing terytorialny w poszukiwaniu nowych kierunków rozwoju}

Podmioty marketingu terytorialnego w procesie budowania swych strategii musza szukać partnerów, z którymi będą wytyczać nowe kierunki rozwoju. Wydaje się, iż uczelnie akademickie są takimi strategicznymi partnerami i mogą budować sieć oparta 
na wzajemnie korzystnych relacjach. Dotyczy to szerokiego systemu budowy społeczeństwa opartego na wiedzy oraz budowaniu innowacyjności i przewagi konkurencyjnej miast i regionów w sferze zarządzania kapitałem intelektualnym i pozyskiwania tego kapitału dla stymulowania procesów rozwojowych.

\subsection{Uniwersytet jako partner miasta i regionu w procesie jego rozwoju}

Dojrzewanie władz samorządowych polskich miast oraz regionów do budowania relacji partnerskich ze środowiskiem akademickim jest w warunkach zjawiskiem relatywnie nowym. Chodzi tutaj bowiem nie tylko o budowanie doraźnych form współpracy, ale o tworzenie trwałych i solidnych podstaw dla partnerskich relacji stron.

Zmianę tego podejścia można porównać ze znanym z rynku przedsiębiorstwem przejściem od marketingu transakcyjnego do marketingu partnerskiego. Stworzenie podstaw dla marketingu partnerskiego wymaga jednocześnie zbudowania trwałych, interdyscyplinarnych form współpracy, związanych ze wspólnym tworzeniem określonych strategii oraz ich realizacją zgodnie z przyjętymi razem założeniami. Sama idea może wydawać się prosta, lecz w warunkach polskich wymaga ona stworzenia bardzo solidnego instrumentarium oraz efektywnych procedur określających nowe mechanizmy i stałe formy konsultacji.

Konsultacje te powinny być prowadzone przez małe i profesjonalne zespoły na etapie poprzedzającym opracowanie strategii (ex ante), na etapie realizacji strategii oraz w fazie następującej po jej wdrożeniu (ex post).W polskich warunkach najsłabszym elementem tego procesu jest tworzenie efektywnych mechanizmów regulujących ten proces z udziałem zainteresowanych stron. Wydaje się, iż wiele działań ma charakter doraźny i w zbyt małym stopniu jest uporządkowane. Dużą słabością jest również faza koncepcyjna służąca wypracowaniu stabilnych i efektywnych form współpracy.

W przypadku miasta i regionu należałoby jednocześnie mówić o współpracy z całym środowiskiem akademickim, a nie tylko z jego wybranymi reprezentantami. Zakłada to także większą integrację środowiska akademickiego na danym terenie, co nie zawsze jest proste $z$ uwagi na tendencje do działań indywidualistycznych poszczególnych ośrodków.

\subsection{Uniwersytet jako dostarczyciel profesjonalnych kadr}

Uniwersytet $\mathrm{w}$ procesie budowania marki miasta i regionu może stać się nośnikiem wielu wartości oraz zasobów wpływających na ich pozycjonowanie oraz na budowanie ich przewagi konkurencyjnej. W sposób naturalny uniwersytet staje się dostarczycielem rzadkich i cennych zasobów, jakimi sa profesjonalne kadry. Zasób ten staje się kluczowy w kontekście poszukiwania źródeł trwałej przewagi konkurencyjnej, opartej na wiedzy oraz na innowacyjności. Dotyczy to zarówno kadr kształconych przez uniwersytety dla potrzeb nowoczesnej administracji samorządowej, jak i kadr edukowanych dla przedsiębiorstw — w tym także z udziałem kapitału zagranicznego 
oraz dla instytucji społecznych, kulturalnych oraz placówek edukacji. W tej sferze uniwersytety, lub szerzej: całe środowisko akademickie, staje się nośnikiem określonych wartości i tym samym potencjalnym argumentem na rzecz konkurencyjnego pozycjonowania regionu. Profesjonalne zasoby ludzkie, dostępne na bardziej konkurencyjnych warunkach, aniżeli w regionach i miastach konkurencyjnych są coraz częściej kluczowym argumentem w procesie budowania marki miasta i regionu w stosunku do inwestorów zewnętrznych: krajowych oraz zagranicznych.

\subsection{Uniwersytet jako nośnik innowacji ważnych dla miast i regionu}

Uniwersytet staje się coraz częściej ważnym stymulatorem lub katalizatorem procesów innowacyjnych generowanych na rzecz miast i regionu. Skuteczność tych działań zależy jednak od orientacji marketingowej samej uczelni oraz od systemu pozyskiwania zewnętrznych źródeł finansowania centrów innowacji, centrów badawczych oraz inkubatorów przedsiębiorczości.

W warunkach polskich pewną słabością marketingu akademickiego pozostaje ciagle niski poziom strategicznej współpracy różnych uczelni z danego miasta i regionu. Dotyczy to zwłaszcza procesu tworzenia interdyscyplinarnych konsorcjów działających na rzecz kreowania innowacji oraz wspólnego wykorzystywania posiadanych zasobów materialnych, sieci kontaktów oraz kapitału intelektualnego. Odczuwa się także bardzo duży niedosyt w zakresie braku synergii pomiędzy różnymi programami kształcenia oraz centrami naukowo-badawczymi.

Działania dezintegracyjne są ciagle silniejsze aniżeli budowanie wspólnych projektów wokół zintegrowanych celów służących stymulowaniu procesów innowacyjnych oraz budowaniu przewagi konkurencyjnej opartej na innowacyjności i synergii działania.

\subsection{Uniwersytet jako niezależny doradca i obiektywny recenzent}

W procesie budowania wzajemnej współpracy z miastem i regionem uniwersytet powinien zachować także rolę niezależnego doradcy władz co pozwoliłoby jego przedstawicielom na przeprowadzanie obiektywnych recenzji, analiz oraz ocen projektów i strategii rozwoju zgłaszanych przez polityków oraz urzędników jednostek samorządu miejskiego oraz terytorialnego. Władza samorządowa na szczeblu miasta i regionu potrzebuje tego typu doradcy, zwłaszcza w zakresie budowania celów strategicznych oraz niezależnej oceny różnych planów rozwoju oraz priorytetów w zakresie wydawania środków publicznych.

Z drugiej strony, istnieje bardzo silna pokusa ze strony władz, aby traktować uniwersytet i środowisko akademickie jako element uwiarygodniania i legitymizacji swoich działań, planów strategii oraz decyzji. Ustawianie się uniwersytetów oraz innych wyższych uczelni w roli „pochlebcy władzy” może stanowić niewątpliwe zagrożenie dla obiektywnych ocen oraz dla wypracowywania oryginalnych rozwiązań. Nie służy to również dobrze budowaniu zasad partnerskiej współpracy stron. 


\section{Marketing partnerski w relacji uniwersytetów z władzami miast i regionów}

Wydaje się, iż świadomość współzależności partnerów w procesie budowania strategii konkurencyjnych jest obecnie dość wysoka. Brakującym elementem, wymagającym ciagłego doskonalenia, jest natomiast niedostatek efektywnych mechanizmów współpracy stron, służących budowaniu trwałej przewagi konkurencyjnej na tle innych miast i regionów.

\subsection{Postrzeganie regionów i miast przez pryzmat uniwersytetów}

Nowoczesne regiony oraz nowoczesne miasta są coraz częściej postrzegane przez pryzmat „swoich” uniwersytetów lub zintegrowanych sieci lub konsorcjów szkół wyższych - harmonijnie ze sobą współpracujących. Uniwersytety są bowiem naturalnym wyróżnikiem i tym samym kluczowym atrybutem marki miasta lub regionu. Dotyczy to zarówno oferty dla studentów, jak i oferty dla przedsiębiorców oraz inwestorów zagranicznych. Rola uczelni jest także istotna w segmencie turystyki biznesowej, konferencyjnej, targowej i festiwalowej, jak również sportowej i rekreacyjnej. Uczelnie wyższe, zwłaszcza w warunkach polskich, są bowiem coraz częściej dysponentami najlepszych zasobów infrastrukturalnych, które mogą być wykorzystywane na tego rodzaju cele. Warto więc wkomponować całość tych zasobów w procesy efektywnego zarządzania miastem i regionem, dla potrzeb budowania ich atrakcyjnego wizerunku.

\subsection{Uczelnie wyższe jako element przewagi konkurencyjnej miast i regionów}

Obecność uczelni wyższej lub, co ważniejsze, harmonijnie funkcjonującego konsorcjum uczelni wyższych, może stać się dla miasta lub regionu elementem jego trwałej przewagi konkurencyjnej. Wyróżnikiem i podstawą przewagi regionu będzie więc coraz częściej preferencyjna sieć powiązań uczelni akademickich i umiejętność ich harmonijnej współpracy na rzecz miasta i regionu. W polskich warunkach czynnikiem wymagającym ciagłego doskonalenia jest harmonizowanie oraz zintegrowanie tej wspólpracy wokól wspólnie akceptowanych celów. Najlepsze wyniki osiagają te miasta i regiony, które potrafią budować ten rodzaj harmonijnej współpracy. W Polsce problem ten nie dotyczy jedynie różnych uczelni, lecz także różnych jednostek działających w ramach tej samej uczelni.

\subsection{Uczelnie wyższe jako element strategii pozycjonowania miast i regionu}

Uczelnia wyższa staje się dzisiaj niewątpliwie elementem wyrazistego pozycjonowania miasta. Chodzi tutaj jednocześnie nie tyle o jedną konkretną uczelnię, ale o całe 
środowisko akademickie, o jego atrakcyjność, innowacyjność, dynamikę oraz relacje międzynarodowe. Studenci wybierając konkretne miasto lub region jako miejsce do studiowania, oczekuja bowiem pewnej unikatowej atmosfery do rozwoju osobistego, gwarancji jakości życia oraz atrakcyjnych form spędzania wolnego czasu. Wymaga to od uczelni wyższych danego miasta, bardziej kompleksowego spojrzenia na produkt marketingu akademickiego w symbiozie $z$ marketingiem całego miasta i regionu. Jest to nowy rodzaj wyzwania dla uczelni publicznych, gdyż de facto konkurują one z uczelniami innych miast. Wymaga to stopniowego odchodzenia od myślenia jedynie w kategoriach oferty jednego uniwersytetu, na rzecz myślenia o łącznej ofercie całej sieci szkół wyższych działających na danym terenie. Przy porównywalnej, równie wysokiej ofercie dwóch uniwersytetów z dwóch różnych miast, potencjalny student będzie wybierał ten ośrodek miejski, którego kompleksowa oferta jest bardziej atrakcyjna.

Mamy więc do czynienia z przenoszeniem akcentu na kompleksowy „produkt akademicki”, związany z danym miastem oraz regionem. Student przy porównywalnej ofercie programowej różnych uniwersytetów zawsze będzie wybierał ten, który znajduje się w mieście „przyjemniejszym do studiowania”. Wydaje się, iż przy porównywalności standardów akademickich te dodatkowe elementy decydujące o „jakości miejsca" będą w przyszłości coraz mocniej zyskiwały na znaczeniu.

Wyzwaniem na przyszłość będzie więc z jednej strony kreowanie „globalnego produktu akademickiego", a drugiej strony budowanie silnych relacji między wizerunkiem tego produktu oraz wizerunkiem miasta i regionu.

Wydaje się, iż produkty edukacyjne obok produktów kulturalnych i sportoworekreacyjnych będą miały w przyszłości kluczowe znaczenia dla budowania pozycjonowania miast i regionów. Wiąże się to zarówno z inwestycjami infrastrukturalnymi w tych wszystkich dziedzinach, jak i z rosnącymi potrzebami ludności w zakresie zaspokajania swoich potrzeb w tychże dziedzinach.

\section{Fundusze europejskie jako platforma do budowania współpracy}

W warunkach polskich programy i fundusze europejskie stały się kluczowym stymulatorem dla nowych i trwałych budowania współpracy między uczelniami oraz władzami miast i regionów. Fundusze europejskie z jednej strony wymusiły oraz przyspieszyły proces budowania strategii marketingu terytorialnego, w ramach szerszych strategii rozwoju miast i regionów, a z drugiej strony — wymusiły budowanie programów partnerskich do kreowania nowych obszarów przewagi konkurencyjnej.

\subsection{Fundusze i programy europejskie jako stymulator relacji partnerskich}

Programy europejskie stały się ważnym punktem wyjścia do bardziej pogłębionej refleksji na temat ścisłych form współpracy miast i regionów z uczelniami akademic- 
kimi. Relacje te stały się jednocześnie ważnym elementem dyskusji na temat innowacyjności oraz tworzenia nowych mechanizmów rozwoju regionu. Relacje uczelni oraz władz miasta i regionu maja w tym zakresie charakter komplementarny. Nowy rodzaj partnerstwa zakłada większą transparentność wzajemnych relacji oraz doskonalenie różnych form i kanałów przepływu informacji. Udrożnienie tych kanałów jest ważnym czynnikiem refleksji nad oceną alternatyw rozwoju.

W warunkach polskich transparentność tego typu działań jest zjawiskiem nowym i niewątpliwie zasługującym na podkreślenie. Potrzebna byłaby natomiast bardzie pogłębiona dyskusja na temat strategicznej roli funduszy europejskich w kontekście rozwoju bardziej pogłębionej współpracy różnych uczelni z danego miasta oraz regionu w celu unikania pomysłów wzajemnie się dublujących.

Wydaje się, iż w tym zakresie ciagle brak jest koniecznej synergii oraz pogłębionej dyskusji na temat celowości różnych inwestycji oraz ich komplementarności.

\subsection{Programy europejskie jako stymulator wspólnych strategii i nowego myślenia strategicznego}

Zasługa programów europejskich może być przede wszystkim stymulowanie różnych form zintegrowanych strategii rozwoju na poziomie miast i regionów. Dezintegracja lub niedostatek form oraz działań integracyjnych jest jedna z kluczowych słabości działań różnych podmiotów w warunkach polskich. Przełamywanie procesów dezintegracyjnych może być widoczne przez generowanie wspólnych projektów przez różne uczelnie danego miasta oraz regionu, unikające podejścia konkurencyjnego i zastępujące ten rodzaj podejścia nowymi formami współpracy.

Nowe myślenie strategiczne zakłada wspólne definiowanie pewnych kluczowych celów strategicznych dla rozwoju miasta i regionu. Chodzi tutaj z jednej strony o wspólne uzgadnianie priorytetowych celów dla rozwoju miasta i regionu, a z drugiej strony tworzenie przez uczelnie wyższe takich projektów - finansowanych z funduszy europejskich, które najlepiej służą realizacji tych celów.

Powinniśmy więc mieć do czynienia z programem uzgodnień i konsultacji celów zarówno w przekroju pionowym, jak i poziomym. Konsultacje w przekroju pionowym zakładają dopracowanie zgodności celów rozwoju regionu oraz miasta (najczęściej stolicy regionu) oraz celów kluczowych uczelni wyższych zlokalizowanych w stolicy regionu. Z kolei system konsultacji poziomych zakłada prowadzenie prac koncepcyjnych i projektowych w interdyscyplinarnym gronie uczelni wyższych danego miasta i regionu.

Wydaje się, iż wszędzie tam, gdzie element konsultacji oraz zintegrowanej współpracy jest warunkiem akceptacji danego projektu jest szansa na stymulowanie tego procesu i zmianę sposobu podejścia do myślenia strategicznego. W warunkach polskich czynnik ten ma ogromne znaczenie, gdyż do tej pory przeważało częściej myślenie partykularne poszczególnych uczelni wyższych przy niedostatku lub braku koniecznej synergii między różnymi partnerami reprezentującymi lokalne środowisko akademickie uczelni wyższych. 


\section{Wspólne strategie komunikacji marketingowej}

Partykularne działania marketingowe — prowadzone osobno na poziomie miasta i regionu — powoduja, iż końcowa efektywność tych działań jest bardzo niska. W zakresie komunikacji marketingowej miasta oraz regionu należy założyć przede wszystkim konieczność prowadzenia spójnych działań przez władze regionu oraz miasta, które jest jego stolica. Działania te powinny być nie tylko spójne, lecz wzajemnie się wzmacniać. W Polsce czynnikiem, który bardzo osłabia spójność tych działań są różnice polityczne powiązane ze strukturą polityczną władz regionu oraz miasta, w trakcie trwania danej kadencji. Obok różnic politycznych drugim czynnikiem hamującym procesy integracyjne w zakresie komunikacji marketingowej są różnice personalne oraz ambicjonalne kluczowych polityków, odpowiedzialnych za proces zarządzania miastem i regionem.

\subsection{Wspólne cele strategiczne}

Warunkiem skuteczności komunikacji marketingowej miasta oraz regionu jest akceptacja pewnych celów wspólnych, które powinny być traktowane jako priorytetowe i mieć wymiar pozapolityczny, a tym samym pozakadencyjny. Zgoda co do wspólnych celów komunikacji marketingowej jest warunkiem budowania spójnego wizerunku miasta oraz regionu w relacji z jego otoczeniem zewnętrznym. Rozwinięciem tych wspólnych celów powinny być działania uniwersytetów i pozostałych wyższych uczelni danego regionu oraz jego stolicy. Chodzi tutaj o przekładanie pewnych kluczowych wyróżników miasta oraz regionu na szczegółowe cele wyższych uczelni tam zlokalizowanych.

\subsection{Wspólne zespoły interdyscyplinarne}

Interdyscyplinarność zespołów roboczych w kontekście strategii rozwoju, a następnie strategii komunikacji marketingowych, zakłada budowanie wspólnej strategii komunikacji marketingowej, wokół pewnych kluczowych wartości, mogących decydować o trwałej przewadze konkurencyjnej danego regionu oraz jego stolicy nad regionami konkurencyjnymi.

Zasada interdyscyplinarności tych zespołów powinna polegać na koordynacji działań władz miasta i władz regionu z opiniami przedstawicielami wyższych uczelni reprezentujących różne dyscypliny oraz specjalności. Podejście to w warunkach polskich byłoby podejściem zupełnie nowym, a jego podstawą byłby minimalny poziom zgody na komunikowanie pewnych wspólnych wartości oraz pewnego stylu podejścia do akcentowania kluczowych dla danego miasta i regionu wyróżników marki. Wydaje się, iż największą wartością byłby tutaj pewien styl podejścia do rozwiązywania oraz komunikowania pewnych wartości. Jednocześnie element ten jest najtrudniejszy do wdrożenia gdyż wymaga pewnego minimum dobrej woli oraz akceptacji zasady współpracy w ramach interdyscyplinarnego podejścia. 


\subsection{Wspólna strategia komunikacji marketingowej}

Wspólna strategia komunikacji marketingowej na poziomie władz miast, regionu oraz wyższych uczelni zakłada zgodę na komunikowanie zewnętrze pewnych wyróżników marki miasta i regionu, które są pozytywne i jednogłośnie akceptowane przez wszystkich partnerów współpracy i które mogą stanowić pewien system wartości z którym identyfikują się wszyscy partnerzy. Mamy wówczas do czynienia z pewną wspólna i jednoznacznie akceptowaną filozofia podejścia do budowania swoich relacji z otoczeniem. Wydaje się, iż w warunkach polskich czynnik ten jest i będzie dość trudny do wdrożenia. Wynika to z ciagle silnego prymatu działań indywidualistycznych przy niedocenianiu wspólnej uzgodnionej platformy komunikacji marketingowej. Czynnik ten ma zarówno wymiar kulturowy, jak i pokoleniowy. Wydaje się, iż młodsze pokolenie rządzących może mieć większą otwartość na cele wspólne i na budowanie wyrazistego pozycjonowania miasta w oparciu o pewien spójny system wartości. Zmiany pokoleniowe na szczeblach władzy mogą więc wpływać pozytywnie na tworzenie nowego klimatu dla tej wspólpracy.

\section{Konflikty między polityką a wspólnymi celami strategicznymi}

W warunkach polskich, szczególnie w przypadku niektórych miast, kluczowym elementem osłabiającym skuteczność działań strategicznych w obszarze marketingu terytorialnego oraz akademickiego jest brak ciagłości pewnych działań strategicznych, wynikający ze zmian w konfiguracji politycznych władz spowodowany cyklem wyborczym.

\subsection{Doraźność działań politycznych}

W działaniach polityków zarządzających poszczególnymi miastami lub regionami występuje ciagle prymat działań doraźnych nad działaniami średnio- i długookresowymi. Takie podejście wpływa bardzo negatywnie na budowanie spójnych strategii rozwoju, w ramach których cele dotyczące marketingu terytorialnego oraz marketingu akademickiego mogłyby się harmonijnie się dopełniać. W tych miastach i regionach, w których występowała ciagłość władzy politycznej i tym samym trwałość realizacji kluczowych celów oraz założeń strategicznych — czynnik ten nie był odczuwany. Natomiast $\mathrm{w}$ miastach $\mathrm{i}$ w regionach, gdzie orientacja polityczna władz podlegała istotnym zmianom, można było wyraź nie odczuć brak konsekwentnego podejścia do realizacji tego typu strategii. W przypadku zarówno marketingu terytorialnego, jak i akademickiego ciagłość oraz konsekwencja w realizacji pewnych celów są warunkiem ich efektywności. 


\subsection{Prymat polityki nad celami wspólnymi}

Dominacja doraźnych celów politycznych nad celami wspólnymi wpływa jak wiemy bardzo negatywnie na kreowanie spójnych strategii marketingu terytorialnego oraz marketingu akademickiego. Ma to tym większe znaczenie, iż większość tych celów jest możliwa do zrealizowania jedynie pod warunkiem stosowania długookresowego podejścia — niezależnego od zmian politycznych we władzach samorządu miejskiego oraz regionalnego.

Sfera ta $\mathrm{z}$ uwagi na swoją kluczową rolę w rozwoju miasta i regionu, wydaje się mało konfliktowa i należy spodziewać się, iż w przyszłości nie powinna być przedmiotem większych rozgrywek politycznych.

\section{Podsumowanie}

\section{Wyzwania na przyszłość}

1. Poszukiwanie spójnego pozycjonowania uczelni wyższych z pozycjonowaniem miasta i regionu.

Kluczowym warunkiem powodzenia opisywanych strategii jest spójność pozycjonowania uczelni wyższych z pozycjonowaniem miasta i regionu. Spójność pozycjonowania polega w tym przypadku na zgodności pewnych kluczowych wyróżników marki miasta i regionu z wyróżnikami marek uczelni wyższych, działających w danym regionie i w jego stolicy. Chodzi tutaj o pewne wartości kluczowe, takie jak: innowacyjność, kreatywność, przedsiębiorczość, otwartość czy międzynarodowość. Wartości te powinny mieć fundamentalne znaczenie zarówno dla marki miasta, jak i dla marek działających w nim uczelni wyższych. Im wyższy poziom spójności wartości tworzących opisywane marki, tym większa spójność oraz wyrazistość pozycjonowania. Warunkiem sukcesu takiego podejścia jest niewątpliwie wspólne budowanie takich strategii. Uczelnie wyższe powinny czuć się współtwórcami takich strategii i tym samym mocno identyfikować się z nimi. Władze miasta i regionu winny natomiast widzieć główne osie kierowanych rozwoju swych jednostek samorządowych we współpracy z uczelniami wyższymi.

\section{Tworzenie strategicznych form współpracy partnerskiej uczelni wyższych}

\section{$\mathrm{z}$ władzami miasta i regionu.}

Współpraca uczelni wyższych z władzami miasta i regionu musi mieć tym samym charakter strategiczny oparty zarówno na stałych formach konsultacji, jak i na istnieniu zespołów interdyscyplinarnych. Członkami tych zespołów powinni być zarówno przedstawiciele uczelni wyższych, jak i władz miasta oraz regionu, reprezentujący różne dziedziny problemowe. W warunkach polskich te formy wspólpracy należą ciagle do rzadkości, a w przyszłości należałoby je tworzyć w sposób 
systemowy. Należy w tym zakresie wypracować nowe formy komunikowania oraz wzajemnych konsultacji o charakterze strategicznym.

\section{Budowanie kompleksowego produktu akademickiego wszystkich uczelni} - poszukiwanie synergii produktowej.

Wyzwania przyszłości polegać będą na poszukiwaniu coraz większej synergii między uczelniami działającymi na danym terenie. Konkurując o tego samego studenta na rynku lokalnym, uczelnie wyższe będą musiały jednocześnie spojrzeć wspólnie na swoją ofertę z punktu widzenia adresatów zewnętrznych, zwłaszcza na rynku krajowym oraz międzynarodowym. Chodzi tutaj bowiem nie tylko o pozyskanie studenta „dla danej uczelni”, lecz równocześnie o pozyskanie studenta „dla danego miasta” lub ,dla danego regionu”.

Obok konkurencyjności partykularnych celów marketingowych, będziemy mieli tutaj do czynienia z komplementarnością oferty różnych szkół. W przyszłości może i powinno to prowadzić do oferowania potencjalnym klientom wewnętrznym oraz zewnętrznych bardziej komplementarnej oraz interdyscyplinarnej oferty edukacyjnej. Podejście to jest ciągle podejściem zupełnie nowym, gdyż opiera się na przekraczaniu pewnej orientacji czysto partykularnej na rzecz orientacji komplementarnej. Dotyczy to zarówno oferty różnych wydziałów tej samej uczelni, jak i, co o wiele trudniejsze, komplementarnej oferty różnych szkół wyższych działajacych na terenie danego miasta lub regionu.

Stosowanie komplementarnych metod pozycjonowania uczelni wyższych byłoby z punktu widzenia pozycjonowania danego miasta lub regionu czymś zupełnie unikatowym (wspólne programy, wspólne dyplomy, wspólne wykorzystanie określonej infrastruktury). W warunkach polskich regionów i miast jest to kapitalny obszar budowania nowej oferty edukacyjnej, opartej na sumowaniu się przewag i kompetencji różnych uczelni wyższych. W obecnych warunkach w realiach najlepszych polskich ośrodków akademickich nie mamy bowiem do czynienia z brakiem nowoczesnej infrastruktury, lecz raczej niekiedy z jej nadmiarem i mało efektywnym wykorzystaniem w skali jednej uczelni. W zbyt małym stopniu wykorzystuje się natomiast synergię akademicką lokalnych zasobów dla budowania przewagi konkurencyjnej miasta oraz regionu, w sferze marketingu akademickiego.

4. Wspólne prowadzenie promocji zewnętrznej miasta i regionu oraz uczelni wyższych.

Wspólne prowadzenie działań promocyjnych jest de facto rozwinięciem i dopełnieniem wspólnej strategii pozycjonowania oraz budowania marki miasta i regionu. Wydaje się, iż dla części polskich miast i regionów ten element ciagle jest nie zrealizowany. Musi on bowiem wynikać ze zintegrowanego podejścia do koncepcji marketingu terytorialnego. Wspólna promocja zewnętrzna powinna wynikać z jednolitego podejścia marketingowego i uzgodnionej koncepcji komunikacji marketingowej dla miasta, regionu oraz środowiska akademickiego. Czynnik ten dotyczyć powinien w szczególności promocji targowej oraz wspólnie organizowanych wydarzeń marketingowych, zwłaszcza w kontekście promocji zagranicznej. Promocja 
zewnętrzna powinna być tutaj bardzo ściśle pozycjonowana na pozyskiwanie precyzyjnie zdefiniowanych grup adresatów. Dotyczyć to powinno również wydawnictw promocyjnych oraz komunikacji internetowej.

5. Dążenie przez miasto oraz region do zatrzymywania najlepszych absolwentów w danym mieście $\mathrm{i} w$ regionie.

W kontekście marketingu akademickiego oraz marketingu miasta, kluczowym miernikiem efektywności powinien być współczynnik osób pozostających w danym mieście po zakończeniu studiów. Dotyczy to zarówno osób pochodzących z danego miasta oraz regionu, jak również, co znacznie ważniejsze, osób przyjeżdżających tutaj na studia. Wspólne oddziaływanie władz miasta oraz regionu na tę grupę „przyjezdnych” absolwentów jest tutaj bardzo dobrym miernikiem atrakcyjności miejsca oraz jakości życia i perspektyw dalszego rozwoju. Władze miast akademickich, które w bardzo niewielkim stopniu potrafią zatrzymać swych najlepszych absolwentów lub też przyciagać absolwentów z innych znaczących ośrodków akademickich powinny zadać sobie pytanie o atrakcyjność swych ośrodków oraz o efektywność swoich działań.

\section{Poszukiwanie kompromisu między myśleniem krótko- i długookresowym.} Wszystkie opisane działania wymagaja znajdywania twórczych rozwiązań i poszukiwania twórczych kompromisów pomiędzy różnymi horyzontami myślenia. Wymaga to jednocześnie nowego spojrzenia na rynek oraz na misję i strategię uniwersytetów w kontekście zintegrowanej współpracy z miastem i regionem w zakresie budowania trwałej przewagi konkurencyjnej w ramach komplementarnych strategii rozwoju.

\section{Streszczenie}

Artykuł ma charakter przeglądowo-koncepcyjny, służy ukazaniu podstawowych wyzwań, które staja przed polskimi uniwersytetami w zakresie budowania przyszłościowej orientacji marketingowej. Celem artykułu jest uporządkowanie podstawowych wyzwań oraz dokonanie klasyfikacji działań strategicznych w odniesieniu do wybranych grup docelowych, do których adresowana jest oferta instytucji akademickich.

Autor wskazuje na potrzebę nowego spojrzenia na definiowanie segmentów docelowych, oferty uniwersytetów w kontekście rosnącej konkurencji rynkowej, zmian demograficznych oraz postępującej internacjonalizacji oraz globalizacji rynku usług edukacyjnych.

Specyfika polskiego rynku edukacyjnego polega na jego bardzo dużej otwartości, rozdrobnieniu i wysokim udziale szkół niepublicznych w ogólnej strukturze podmiotowej rynku. Przyszłościowe strategie marketingowe powinny uwzględniać daleko idącą dywersyfikację gamy oferowanych usług edukacyjnych oraz coraz szersze zorientowanie uniwersytetów na rynki zagraniczne.

\section{Słowa kluczowe}

Marketing akademicki, marketing partnerski, promocja miast i regionów, orientacja marketingowa uniwersytetów, orientacja rynkowa uniwersytetów, strategie marketingowe uniwersytetów polskich, marketing terytorialny, synergia strategii w marketingu terytorialnym i akademickim. 


\section{Bibliografia}

1. Domański T., Ksz̧tatcenie studentów w jezykeach obych. Wybrane doświadczenia Wydżiatu Studiów Międzynarodowych i Politologicznych na Uniwersytecie Lódzkim, [w:] Kształcenie dla potrzeb spoteczeństwa europejskiego. Szkoty z. klasami dwujezycznymi w Lodzi - 1998-2008, pod red. M. Szewczyka, Instytut Europejski, Łódź 2008, s. 31-33.

2. Domański T., Marka Łodżi wyrastajaca z. tożsamości miasta, „Kronika Miasta Lodzi. Kwartalnik", nr 4, Lódź 2009.

3. Domański T., Kowalski P., Marketing dla menedżerów, Wyd. I, PWN, Lódź-Warszawa 1998, wyd. II 2000, ss. 360.

4. Domański T., Marketing dla miasta i regionu. Ekspansja çy regres myślenia marketingowego?, [w:] Ekspansja czy regres marketingu?, Polskie Wydawnictwo Ekonomiczne, Warszawa 2006, s. 395-400.

5. Domański T., Marketing edukacyjny w warunkach globalizacji rynku, [artykuł w materiałach pokonferencyjnych:] III Konferencja z cyklu „Marketing szkół wyższych” pt. „Współczesne trendy w orientacji marketingowej szkół wyższych”, 5-7 marca 2008 r. Wyższa Szkoła Bankowa w Poznaniu, Poznań [w druku].

6. Domański T., Marketing miasta. Wyz̨wania strategiczne, [w:] Marketing terytorialny. Możliwości aplikacji, kierunki roz̧woju, red. H. Szulce, M. Florek, Wydawnictwo Akademii Ekonomicznej w Poznaniu, Poznań 2005, s. 75-83.

7. Domański T., Marketing terytorialny — wybrane aspekty praktyczne, [w:] Marketing terytorialny. Strategiczne wyz̧wania dla miast i regionów, praca zbiorowa pod red. T. Domańskiego, Uniwersytet Lódzki, Lódź 1997, s. 19-30.

8. Domański T., Międzynarodowy model ksz̧tałcenia studentów, „Przegląd Edukacyjny” 2009, nr 1 (styczeń-luty), s. 7-9.

9. Domański T., Skuteczna promocja miasta i regionu podstawowym zadaniem marketingu terytorialnego, [w:] Marketing terytorialny, pod red. Tadeusza Markowskiego, „Studia”, tom CXII, Polska Akademia Nauk, Komitet Przestrzennego Zagospodarowania Kraju, Warszawa 2002, s. 137-158.

10. Domański T., Skuteçna promocja miasta i regionu podstawowym zadaniem marketingu terytorialnego, [w:] Marketing terytorialny, pod red. Tadeusza Markowskiego, tom CXVI, Polska Akademia Nauk, Komitet Przestrzennego Zagospodarowania Kraju, Warszawa 2006, s. 124-140.

11. Marka dla Łodzi. Strategiczne budowanie wizerunku miasta, pod red. T. Domańskiego, Wydawnictwo Katedry Marketingu Międzynarodowego i Dystrybucji Uniwersytetu Lódzkiego, Łódź 2008, ss. 159. 